\title{
O NACIONALISMO DE ALBERTO TORRES E OLIVEIRA VIANA NA CONSTRUÇÃO DO PENSAMENTO CONSTITUCIONAL BRASILEIRO
}

\author{
Guilherme Miraldi da Silva Santos ${ }^{291}$ \\ Sérgio Silveira de Oliveira ${ }^{292}$
}

Recebido em: 28/09/2016

Aprovado em: 20/03/2017

\begin{abstract}
RESUMO
Busca-se estudar e questionar, no presente trabalho, o conceito de "periferia" como característica do Brasil em relação a supostos países cêntricos, não somente, uma hipotética posição hierarquicamente inferior nos âmbitos culturais, políticos sociais etc. Analisa-se as teorias que defendem e atacam tais ideias buscando sempre um entendimento que não caia em anacronismo acadêmico tampouco exclua do período vigente suas características e peculiaridades sine qua non para a crítica dos juízos valorativos de cada época. Ademais, utiliza-se o trabalho " $A$ organização Nacional" de Alberto Torres e "O idealismo da Constituição" de Oliveira Viana como bibliografia imprescindível para a compreensão da influência do pensamento nacionalista no movimento constitucional brasileiro, além disto, a influência prática de suas teorias na história.
\end{abstract}

Palavras-chave: Estrangeirismos. Inadequação. Nacionalismo.

\section{INTRODUÇÃO}

Ao nível de uma análise de conteúdo, busca-se analisar, no presente trabalho, a base de sustentação teórica do Brasil como lugar periférico e inferior e as respectivas ideias que atacam tais concepções. Procura descrever e questionar suas múltiplas consequências no universo jurídico, político, econômico, cultural, social etc. Utiliza-se o modo comparativo, com ênfase, nas peculiaridades dos países ditos cêntricos (países da Europa e Estados Unidos da América

\footnotetext{
${ }^{291}$ Mestrando em Direito pela Universidade Veiga de Almeida. Especialista em Direito Público pela Instituição Toledo de Ensino (Damásio de Jesus) e Pós-graduação em Psicopedagogia pelo Centro Universitário Barão de Mauá. Bacharel em Direito pela Universidade Federal Fluminense. Advogado.

${ }^{292}$ Mestrando em Direito pela Universidade Veiga de Almeida. Especialista em Direito Processual Civil pela PUC/RJ. Bacharel em Direito pela Universidade Veiga de Almeida.
} 
do Norte) e suas características culturais e jurídicas com a realidade brasileira e uma possível inadequação do uso de um mimetismo sem analisar as peculiaridades nacionais.

Busca-se entender a priori o pensamento constitucional de Alberto Torres e Oliveira Viana e analisar a consequência de suas teorias, a posteriori, as consequências de suas teorias na história brasileira. Procura-se neste trabalho aferir a realidade do movimento constitucional brasileiro que se faz tanto no plano da demanda do "dever ser" constitucional em uma tentativa de "modernização" da sociedade como a necessidade da existência de normas constitucionais que se adequem minimamente as características e peculiaridades inexoráveis na aplicação prática da jurisdição nacional. Sendo assim, se faz necessário analisar os ideais valorativos de cada época, equilibrando com a necessidade de compor as finalidades das normas com a capacidade mínima de aplicabilidade e harmonia com a sociedade brasileira de cada período.

Ademais aplicar um olhar crítico sobre as demandas constitucionais de cada época histórica citada utilizando uma metodologia que traduza a tentativa de compor as demandas sociais de cada período conjuntamente com a tentativa de retirar do Brasil o estigma pejorativo de lugar periférico e inferior, não somente analisar se algumas dos ideais defendidos à época seriam anacrônicas frente as diferenças econômicas e tecnológicas da atualidade conjuntamente com a realidade de um mundo muito mais globalizado.

\section{METODOLOGIA}

Quanto aos fins, esta pesquisa será descritiva e explicativa. Descritiva porque buscará analisar como se forma o pensamento de um país como "periférico" e inferior. Explicativa porque intentará esclarecer os motivos os quais dificultam o espancamento das ideias do Brasil como país "periférico" e inferior frente a países considerados cêntricos (países europeus e Estados Unidos da América do Norte), aplicando um olhar acurado sobre as relações de poder, o contexto histórico, religioso e cultural sobre sociedade que fortalecem este viés valorativo.

Visa assim descrever a ideia de como um país "periférico" e supostamente inferior encontra suporte teórico, não somente, busca descrever a sua referente contestação política, literária e cultural. Em especial, utilizando os trabalhos "A organização Nacional" de Alberto Torres e "O idealismo da Constituição" de Oliveira Viana. Busca explicitar o pensamento Constitucional antes de Alberto Torres e Oliveira Vianna, abordando o mimetismo e as normas 
supostamente inadequadas a realidade nacional, não somente as consequências reais das ideias defendidas por tais autores sem perder o espírito crítico e acadêmico.

Ademais, o trabalho será explicativo com base em autores clássicos de amplas áreas do saber humano que contribuam ou enriqueçam o entendimento dos pontos a serem estudados.

Quanto aos meios, a pesquisa será bibliográfica e documental. Bibliográfica, porque a fundamentação teórico-metodológica da pesquisa terá por base Códigos, obras de doutrinadores do Direito e obras de cunho psicológico, sociológico e antropológico, indispensáveis para entender o tema. Documental, porque será fundamentada em publicações de revistas, jornais, em documentos eletrônicos. As fontes desta pesquisa serão as obras de doutrina do Direito, os Códigos e leis, assim como obras que tratem do objeto da pesquisa sobre uma abordagem sociológica, psicológica e antropológica. Utilizar-se-á na pesquisa, artigos em redes eletrônicas, documentos e matérias publicadas em revistas e jornais. Os dados serão coletados em fontes bibliográficas, sites acadêmicos. Interpretados com redação própria serão os conteúdos doutrinários e a legislação utilizadas, contudo utilizando-se de transcrições, quando for necessário, para que não seja alterado o sentido dado pelo autor.

\section{O PENSAMENTO DO BRASIL COMO PAÍS PERIFÉRICO E INFERIOR}

O título do artigo "Por que pensamento e não teoria? A imaginação político-social brasileira e o fantasma da condição periférica (1880-1970)" do doutor Christian Lynch traduz um aspecto importante da consideração do Brasil como país periférico: o paradoxo do fantasma o qual se por um lado não existe, por outro, no campo do imaginário e da cultura, de fato tem consequências totalmente reais em diversos campos como política, Direito, economia, etc. Destarte, tanto como imaginário como nas consequências desta concepção é enormemente importante e frutífero a investigação sobre este tema.

Em síntese busca-se entender por que se chama a reflexão política brasileira de pensamento e não teoria. Explorando a hipótese de que as elites brasileiras consideram seus produtos intelectuais ${ }^{\mathbf{2 9 3}}$ inferiores, revelando um caráter periférico em relação aos países considerados cêntricos (países da Europa e Estados Unidos da América do Norte).

\footnotetext{
${ }^{293} \mathrm{O}$ texto em questão frisa a questão dos produtos intelectuais, entretanto, a leitura sistemática também pode explicar a produção brasileira de modo geral, estigmatizando de forma pejorativa qualquer objeto nacional tal como um fetiche de qualquer objeto ou característica de países considerados cêntricos serem taxados como superiores, fazendo com que na prática ora se menospreza qualquer fator de existência nacional ora se
} 
Durante um século e meio de existência da nação houve a hegemonia do regime eurocêntrico e evolucionista de historicidade fazendo com que autores nacionais ou menosprezassem ou até mesmo ignorassem por completo as produções nacionais. Entretanto, sem que haja nenhuma base intelectual plausível para sua sustentação este pensamento ainda não está totalmente superado o que impulsiona o seu estudo de uma forma profunda e atenta para a manutenção de uma postura discriminatória e preconceituosa.

Segundo Lynch, teoria significa: “A palavra 'teoria' costuma ser empregada para designar um conjunto de proposições lógico-abstratas que descrevem as leis de funcionamento de um determinado fenômeno. "(LYNCH, 2013, p. 5).

Lynch enumera inúmeros tipos de teorias que incluem o currículo de ensino superior, como filosofia, Direito, sociologia, antropologia, economia, história, teoria política etc. $\mathrm{Na}$ filosofia e na teoria política, o método de ensino é autoral, sendo assim, se estuda com leituras de autores considerados “clássicos” como Maquiavel, Hobbes, Locke, Montesquieu, Rousseau, etc. Todavia, o mesmo método é utilizado para estudo disciplinar de obras políticas brasileiras, utilizando-se de "grandes livros" de autores "clássicos" como visconde de Uruguai, Tavares Bastos, Joaquim Nabuco, Rui Barbosa, Alberto Torres, Oliveira Viana, Sérgio Buarque, Raimundo Faoro etc. Esta disciplina se chama: pensamento político-social brasileiro, pensamento social e político brasileiro ou simplesmente pensamento político brasileiro.

Obviamente, não há como não se perguntar por que há esta distinção. Lynch (LYNCH, 2013, p. 6) é objetivo ao afirmar que a resposta não é simples. A primeira hipótese é que seriam expressões intercambiáveis, a segunda hipótese é de que textos teóricos ou filosóficos seriam coerentes, abrangentes e abstratos enquanto os de pensamento seriam fragmentários, contingentes ou assistemáticos. Desta forma poderia ser observado, no primeiro, um universalismo e estudo da verdade, enquanto na segunda, da opinião e da pontualidade local. Ademais, os textos teóricos seriam desapaixonados e contemplativos enquanto no pensamento haveria a manifestação por meio de leis, códigos, poemas, história das ideias, panfletos e discursos públicos. Na filosofia política autores como Platão, Locke, Montesquieu. No pensamento político autores como Jefferson, Constant, Guizot.

supervaloriza os de origem "cêntrica". Em cultura política brasileira Lynch descreve que o etnocentrismo da cultura europeia levava a crer que as características múltiplas do país eram consideradas como negativos, como geografia, clima, combinações étnicas da população, técnicas de cultivo e praticas religiosas. (LYNCH, 2013, p.3) 
Lynch admite a existência destas justificativas, entretanto adiciona outro entendimento, a de que há uma concepção de que o país se encontra em tempo difuso (atrasado) ${ }^{294}$ e em posição locacional (periférica) no mundo. Uma percepção das elites ibero-americanas de se acharem excluídas do centro do mundo, algo que repercutiu na posterioridade nas independências dos países latino-americanos e na construção da identidade nacional (LYNCH, 2013, p. 7).

Desta forma, havia a percepção de que os autores dos países "cêntricos" produziam conteúdos filosóficos e universalistas enquanto os países periféricos "pensamentos”, conteúdos precários, fragmentários, assistemáticos e nacionais. O irônico é que não havia um conteúdo que justificasse a existência de um universalismo das ideias dos países "cêntricos", apenas a crença de que aquilo produzido era a verdade e o belo, sendo assim, obviamente seriam considerados válidos para todo o mundo. Indubitavelmente o sentimento de que a América do Sul era um local periférico e atrasado de fato estava arraigado nos europeus ou descendentes de europeus aqui viviam, ademais, após as independências dos países latino-americanos e o desligamento dos países "cêntricos" como sociedade e nação criaram um sentimento nas elites de desligamento e expatriação:

\begin{abstract}
A imagem do brasileiro culto sentindo-se expatriado no próprio país, alheio à própria cultura da população local, seria formulada em 1922 por Lima Barreto, em Transatlantismo: "Nós, brasileiros, somos como Robinsons: estamos sempre à espera do navio que nos venha buscar da ilha a que um naufrágio nos atirou" (Barreto, 1922). Em 1932, em Brasil errado, Martins de Almeida diria: "O brasileiro é um exilado dentro da própria terra" (Almeida, 1932, p. 53, grifo nosso). Quatro anos depois, Sérgio Buarque de Holanda se limitaria a repetir a fórmula de Almeida, em Raizes do Brasil: "Somos ainda uns desterrados em nossa terra" (HOLANDA, 1936, p. 3). (LYNCH, 2013, p. 10).
\end{abstract}

Em “cultura política brasileira” Lynch traduz a importância da autoridade linguística em relação a cultura e a autoridade política. Isto se dá porque a legitimidade das funções políticas é alocada dentro do universo das ideologias e dos discursos que há em seu interior. Neste contexto, as demandas das sociedades em diferente lugar e tempo consagraram discursos diversos e valores relativos a cada necessidade (LYNCH, 2015, p. 1). A cultura política brasileira (como a cultura de outros países considerados periféricos e atrasados) se expunha como uma elite que se esforçava para aprender e modelar a realidade local com base na história

\footnotetext{
${ }^{294}$ A concepção de que as nações periféricas estariam vivendo o passado do progresso evolutivo dos países "cêntricos", sendo assim, estariam em anormalidade em relação ao tempo. Esta filosofia da história ou cronosofia serviu e serve como base de legitimação da influência dos países "cêntricos" nos países "periféricos", ou seja, a imposição graciosa ou impositiva da cultura "cêntrica" favoreceriam a civilização e o desenvolvimento das culturas atrasadas.
} 
e nos ensinamentos dos países "cêntricos"295. Estas demandas muitas vezes não considerava as características e peculiaridades locais o que transformavam muitos ideais e práticas como inadequadas $^{296}$. No contexto do autoritarismo, liberalismo e socialismo estas demandas se tornaram, na prática brasileira, ideais que confrontavam a capacidade de efetivação e objeto político demasiadamente delicado por inúmeras vezes, ou seja, muitas vezes os valores e os discursos enfrentavam dificuldades fáticas na sua aplicação e eficácia. No Brasil havia a ideologia de modernizar os países e avançar no desenvolvimento em direção a normalidade dos países “cêntricos". Neste contexto muitas características imperiosas e fáticas foram ignoradas.

Três diagnósticos foram estabelecidos para explicar a dificuldade efetividade da cultura e política "cêntrica": (1) O atraso do país real frente ao país legal (2) a inefetividade do país legal sobre o real (3) Adiantamento demasiado do país legal diante do real (LYNCH, 2015. p. 6-10). Não somente, outras estratégias foram formadas com o intuito modernizador: o pedagogismo e as vanguardas modernizadoras. O pedagogismo no qual consistia em educar as elites e a população para alcançar níveis de instituições políticas "cêntricas". Já as vanguardas modernizadoras enxergavam que, por meios naturais, seria incapaz o povo ou a sociedade civil conduzir um processo de desenvolvimento por vias da evolução liberal democrática. Era necessário desentravar os obstáculos ao progresso (LYNCH, 2015, p. 11-12).

As vanguardas burocráticas tinham três vieses: O governante. (LYNCH, 2015, p. 11) A ideia de um governante forte, capaz de ultrapassar os desafios burocráticos e políticos levando ao povo as suas necessidades. Figuras, por exemplo, como Getúlio Vargas, João Goulart, Luis Inácio Lula da Silva. ${ }^{297}$ (1) Os militares. Porta-vozes de inspirações positivistas e jacobinas no

\footnotetext{
${ }^{295}$ Inglaterra, França, Estados Unidos da América do Norte.

${ }^{296}$ O que fora atado pelos autores Alberto Torres e Oliveira Viana e será objeto de estudo no capítulo posterior.

${ }^{297}$ De fato, a figura do governante forte, algumas vezes criticado negativamente como "populista", outras vezes positivamente como "Estadista", inegavelmente tem sua imagem marcada na cultura popular como este Samba de reflexos do getulismo, impregnada da ideologia nacional-estatista, "feito por Silas de Oliveira e Walter Rosa para a peça Dr. Getúlio, sua vida e sua glória, de Dias Gomes e Ferreira Gullar": Legado de Getúlio (1968) (CIVITA, 1977, p. 1)

Entristecido /Pelo rude golpe que sofreu/O povo brasileiro presta sua homenagem comovido /Ao grande patriota que morreu/Getúlio Vargas/Que relembramos com amor/Sua voz meiga nunca mais se ouviu/Falando ao povo sofredor/Trabalhadores do Brasil/Foi em 1930 à frente da revolução /Getúlio Vargas assumiu /A presidência do Brasil/Era um tempo novo que se abria /E o desenvolvimento industrial /As leis trabalhistas ele cria /E a previdência social/Eram tempos de conquistas /E de grande agitação pelo poder/De 32 a 37 aquele estadista/Reprimiu os comunistas e integralistas/Mas não há quem esconda seu valor idealista/Basta falar em Volta Redonda/Basta falar na Petrobrás/Símbolos vivos dos anseios nacionais/Em 45 Getúlio Vargas foi deposto /Por um golpe militar/Para voltar em 51 ao mesmo posto Nos braços do povo/Eleito pelo voto popular/Na última etapa de seu governo /Getúlio enfrentou o inferno /E a incompreensão/Sob a fúria assassina/Das aves de rapina/Que queriam o ouro e o sangue da nação/Ofendido e humilhado /Pelo próprio povo abandonado/Getúlio já na solidão/Coberto de calúnias e de Glórias/Meteu uma bala no coração/Saiu da vida para entrar na História/E daquela carta derradeira /O povo fez sua bandeira/Na luta pela emancipação /Onde ele afirma muito bem/“O povo de quem fui escravo jamais será escravo de ninguém" (CIVITA, 1977, p. 1).
} 
final do império afirmavam (Benjamim Constant e Lauro Sodré) que os militares eram "cidadãos fardados". Os militares seriam os mais patriotas de todos os cidadãos. Aqueles dispostos a dar a vida pela pátria. Ideologia que teve papel importante no golpe republicano de 1989. O militarismo com ideal salvacionista voltou a manifestar-se durante a presidência do Marechal Hermes da Fonseca. No movimento tenentista na década de vinte. Como defensores dos ideais nacionais ao invés de políticos profissionais em 1937, 1945, 1954, 1955, 1961, e 1964. (LYNCH, 2015, p. 12). (2) A magistratura e o ministério público com a redemocratização do país na década de 1980, a vanguarda passou dos militares para magistrados e promotores em especial os de esfera federal. A Constituição Federal de 1988 criou um ambiente propício a esta aspiração política com a independência da magistratura e do Ministério Público, ademais, o neoconstitucionalismo e o ativismo judicial como fatores de efetivação dos anseios e necessidades nacionais. A busca de uma "Sociedade Republicana" em face da inépcia e da corrupção da classe política. Posição defendida por sociólogos como Luiz Werneck Viana e juristas como Gilmar Mendes, Joaquim Barbosa e Luís Roberto Barroso. (LYNCH, 2015, p. 14).

\section{O PENSAMENTO NACIONALISTA DE ALBERTO TORRES E OLIVEIRA VIANA}

Alberto de Seixas Martins Torres (1865-1917) foi político, jornalista e bacharel em Direito. Exerceu a função de presidente do Estado do Rio de Janeiro e também foi ministro do Supremo Tribunal Federal. Em sua produção literária e política era crítico do mimetismo de ideias jurídicas que vinham do exterior, ou seja, denunciava a alienação de ideias que havia no Brasil. Segundo Alberto Torres a jurisprudência constitucional de sua época vinha dos conceitos e comentários da doutrina e da jurisprudência americana e no campo do Direito privado havia ilustrações e comentários da doutrina e jurisprudência portuguesa e francesa.

Alberto Torres enxergava a necessidade de orientar e organizar o país em função de suas próprias características, peculiaridades e fisionomia, o que evitaria a desordem social e moral e traria desenvolvimento ao Brasil. A sua mais significativa produção é "A Organização Nacional" a qual sugere a desorganização do país a qual seria prejudicial à nação e ao povo brasileiro, este que era nobre, entretanto era governado por uma Constituição Federal que não respondia as necessidades e anseios da nação. 
Na terceira seção de "A Organização Nacional” em uma escrita que não segue uma linearidade tópica, "Da Revisão Constitucional", é defendido no ponto I "A união e as províncias: princípios fundamentais”, a alteração da denominação da República Brasileira (TORRES, 1982, p. 315), a qual foi inspirada no da norte-americana, esta que fortaleceu a opinião, dominante na política, de que os Estados são dotados de uma autonomia que assume de fato as proporções da soberania.

Dominava o espírito do legislador constituinte o pensamento de fortalecer os Estados. Os homens que organizaram o regime tinham ardente ambição de autoridade local; daí a carência de condições práticas de soberania efetiva, nas funções da União. A Constituinte teve espírito de reforma e espírito jurídico: não teve espírito político. Coleção de preceitos sem assento na vida real, a Constituição não recebeu o influxo de um pensamento político dominante, que desse às instituições o fluido inspirador e a ideia motora de um objetivo superior e prático, nem métodos e critérios de orientação que enfeixassem seu conjunto num corpo homogêneo e animado. A denominação Estados Unidos do Brasil traduz este espírito da Constituição. É preferível o nome: República Federativa do Brasil, devendo os atuais Estados passarem a chamar-se províncias autônomas. (TORRES, 1982, p. 315).

Observa-se em Alberto Torres a busca pela ordem e organização da nação com o fortalecimento das competências e da força política da União. O artigo VI é visto pelo autor de forma negativa, na qual a sua interpretação dada com tendência estadualista e o critério de exegese jurídica, dominantes no espírito dos homens públicos seria a causa da consolidação desse estado de coisas que fez dos vinte Estados ou vinte eixos da política do país, assim desmembrada em outras tantas tendências, opostas e em conflito. Fazendo com que grupos políticos estaduais (ou melhor, grupos partidários) mais fortes que a autoridade nacional. A atividade pública nacional é feita do amálgama de suas concentrações passageiras em torno dos governos locais, atadas, por conchavos pessoais, em partidos nacionais. (TORRES, 1982, p. 316)

Para Torres a constituição deveria trazer harmonia entre a carta política e a sociedade. O espírito do país ainda não tinha assimilado a noção deste papel político dos diversos membros da União e dos outros poderes públicos. Afirmava que essa era a essência da constituição onde a mesma era a expressão, o leito e o reflexo da vida nacional, o espelho de seu desenvolvimento, como na Inglaterra e nos Estados Unidos. No primeiro feito por textos esparsos, costumes e tradições. Textos que evoluem com a marcha da sociedade e as transformações de costumes e tradições. Com isto há se faz adaptar, substituir, caducar e reaparecer, sem que haja infração ou 
conflito da lei. Lei esta que se faz com senso superior da política a arte de efetuar o acordo das normas com a vida da sociedade. A palavra "Constituição", envolvendo a ideia de que esta lei é a expressão da vida nacional, tem o valor de seu sentido fisiológico: É uma predicação política feita para assinalar que é uma lei adaptada à realidade social, obedecendo a fins práticos, não só originariamente inspirada em certa ordem de objetos gerais e permanentes, mas ordinariamente dominada pelo escopo de sua aplicação ao desenvolvimento evolutivo da sociedade (TORRES, 1982, p. 317).

Alberto Torres toca em um ponto ainda muito atual, o desvirtuamento da palavra “política", (TORRES, 1982, p. 317) que faz surgir, nos espíritos, certa repugnância à aceitação desta inteligência constitucional. Quando não considerada como arena de lutas pessoais, a política é tida como uma luta partidária, entre homens que pleiteiam certo número de princípios teóricos. A concepção acadêmica do Governo e do Estado, fundada sobre a pressuposição de sistemas, normas e princípios permanentes, sugeriu a ideia da separação entre as regras e programas, e as realidades da sociedade, do homem e da terra. Daí, a existência das políticas dos partidos, em todas as nacionalidades, e a falta da política nacional. Nos velhos países, esta política existe, e é inconscientemente seguida, com relativa aproximação aos interesses concretos e às necessidades positivas; entre nós, ela falta completamente.

Torres pontua a realidade americana com relação a união nacional na qual o conceito americano de que a Constituição é uma carta de princípios enumerados e, portanto, limitados, adotado doutrinariamente no brasil em parte- com flagrante contradição. A ideia de que a união nacional é uma unidade convencional com Estados como verdadeiras entidades políticas é natural no pensamento da Constituição Americana. No Brasil há o mesmo princípio jurídico, mas em contradição com antecedentes históricos. Torres salientava que uma Constituição Federal deveria ser ativa, eficiente e eficaz, reclamando a ineficiência da carta magna vigente. Segundo Torres (TORRES, 1982, p. 322) “um país constitucionalmente organizado não pode tolerar, em seu território, regiões ou populações que não vivam à sombra da lei, garantidas com a posse serena de seus direitos, com os recursos e meios de cultura e civilização, que leis e autoridades têm por missão assegurar". Neste âmbito (TORRES, 1982, p. 323) afirma que as intervenções da união nos Estados teriam cabimento para tornar efetivas as garantias constitucionais à liberdade, à segurança e à propriedade dos cidadãos. Também afirma que nas Constituições latinas não há instrumentos ou processo prático para tais garantias legais. Não havia garantias tampouco segurança prévia para direitos patrimoniais. Neste ponto, Torres diferencia a Constituição Belga para a Magna Carga inglesa, nas quais ambas tinham como 
garantia à liberdade e à segurança individual, contudo, no primeiro caso havia ausência de todo instrumento efetivo de proteção judiciária e já no caso Inglês havia o remédio habeas corpus o qual tornava efetivo as normas constitucionais.

Ademais, segundo Torres:

No Brasil o excesso de pessoal nos estabelecimentos oficiais e o protecionismo, avolumaram, muito além do necessário, as populações operárias urbanas. As obras voluptuárias das cidades trouxeram ainda maior sedução para os trabalhos urbanos; e a proteção legal e amparo moral efetivo aos reclamos desses operários produziram os seguintes resultados: criar uma aristocracia proletária oficial, privilegiada sobre todos os outros operários e sobre outras classes não menos laboriosas; e favorecer o trabalho nas cidades, contra o trabalho no campo. (TORRES, 1982, p. 327).

Este problema de uma criação de uma aristocracia proletária (em especial do trabalhador urbano versus trabalhador rural) se faz muito danoso à sociedade.

Há também a denúncia do problema dos colonos estrangeiros conjuntamente com o abandono ao brasileiro. Torres via como um escândalo e absurdo o ardor com que os governantes se empenhavam em estabelecer e instalar colonos estrangeiros, dando-lhes propriedades e instrumentos de trabalho, ao passo que abandonavam à ociosidade não poucos milhões de compatrícios. Não somente denunciava que a instrução secundária e a superior eram um privilégio e destino dos filhos dos abastados; injustiça e perda de valores intelectuais para o país.

Ademais, (TORRES, 1382, p. 330) deveria haver intervenção governamental na economia, esta que deveria fomentar a produção de tudo quanto interessar à vida, à saúde, ao bem-estar, à propriedade e à educação dos brasileiros. (TORRES, 1382, p. 332). (TORRES, 1382, p. 335). Nacionalização de atividades com grande valor social e econômico como a navegação da cabotagem por navios nacionais, ser também nacionais as estradas de ferro, empresas de viação e navegação interior, como todas as que explorarem negócios ou indústrias de interesse vital para a Nação, não somente, nenhuma empresa, companhia ou sindicato poderia explorar no país, indústria, comércio ou produção de qualquer natureza, se não tiver sede no território nacional, e na direção, na administração e no pessoal, brasileiros e estrangeiros residentes e domiciliados no território nacional.

Alberto Torres (TORRES, 1382, p. 336) sugere a modificação do artigo 15 CF com a inovação da criação do poder coordenador o qual teria por fim (TORRES, 1382, p. 344) fortalecer a ação governamental, a ligar solidariamente as instituições do país e a estabelecer a continuidade na prossecução dos ideais nacionais. 
No Brasil é (TORRES, 1382, p. 338) imperioso haver autonomia provincial, pois era um país no qual a carta geográfica o impunha. País extensíssimo, de climas variados, com regiões de caracteres, naturezas e produções diferentes, seria simples violência recusar-se a cada uma de suas circunscrições a faculdade de governar seus interesses mais íntimos, de acordo com as inspirações próprias de seu meio, escolhendo livremente os seus mandatários. No Brasil não há federação e não haveria regime unitário por força legal. Enquanto na federação há abuso estatal no império o unitarismo do regime trazia inércia e formalismo. No Brasil havia desmembramento, com rótulo de federação política.

Alberto Torres (TORRES, 1382, p. 338) faz a comparação da cultura profissional e econômica nos Estados Unidos e no Brasil. No primeiro a educação argentária do ianque produziu o tipo de seu homem representativo: o struggler-for-life de Wall Street. No segundo a educação literária do brasileiro produziu o candidato a emprego público e o político (obra genuinamente imperial).

Destaca-se a defesa da busca da ocupação dos problemas da nossa nacionalidade, da nossa sociedade, da nossa gente e da nossa terra. Torres critica a visão política superficial das classes superiores da sociedade. Defende a existência do estadista (avis rara na história e que não é ave da nossa fauna) o que não se pode inventar. Deveria ter projeto no Brasil a corrigir os defeitos do regime democrático e a indicar os meios de adaptá-lo, bem como o regime federativo, à nossa terra, ao nosso povo.

Já em Oliveira Viana em “O idealismo da Constituição" é defendido que o movimento em prol da velha "tese" democracia revive-se antigos debates sobre soberania do povo, direito do sufrágio universal, representação política e princípio de liberdade. Ressalta-se a importância de que esses debates ocorressem em São Paulo, centro de irradiação de ideias. Com um olhar sobre os agitadores, Oliveira Viana, classifica-os de mais interessantes que as ideias, pois constata que a mentalidade dos agitadores de hoje, nada mais é que a mentalidade dos agitadores de ontem: os mesmos que sonharam a independência, a Constituinte Imperial, a Constituinte Republicana, etc. São na verdade ideias, processos e objetivos guardados por décadas em "gavetas" e ocasionalmente usadas. O que difere é que os agitadores de hoje podem refletir com base numa experiência de Democracia.

O ponto crucial da questão (VIANA, 1939, p. 11) é como esses agitadores de hoje usaram essa experiência na formação de suas ideias políticas e reformadoras. A resposta deve passar pela categoria de espírito de cada agitador, pois, tanto faz, "como afirma JUNG cem anos de experiência, um ano de experiência ou nenhum ano de experiência, uma vez que tudo se 
iguala a nada". No caso dos republicanos, como afirma Nabuco: "uma pura arte de construção no vácuo: as bases são as teses e não os fatos; o material, ideais e não os homens; a situação, o mundo e não a paz; os habitantes, as gerações futuras e não as atuais" O grande problema é evoluir da situação atual (Democracia de Opinião) para uma Democracia de Opinião Organizada.

Quando confrontadas, a Constituição Imperial x a Constituição Republicana, veremos que a primeira tinha a seu favor as grandes lideranças do país, tanto com campo da inteligência, do prestígio cultural, do caráter e da condição social, representantes da nação comprometidos com um ideário de construção de um país. Já a Constituição Republicana, nascia sob o aval de "agitadores" que acreditavam que apenas belos artigos promoveria o salto do país para patamares mais evoluídos. Com o advento da República, essas velhas lideranças foram colocadas de lado, abrindo espaço par inúmeros clãs, que não só fragmentou o poder central, como também, a unidade de pensamento já existente. Esses grupos espalhados pelo país deram origem aos partidos políticos, sem estruturas de caráter, escrúpulos e experiência, tomando de "assalto" o poder das lideranças da Constituinte Imperial, dotadas de valores e ideais políticos.

Acontece que os "moços" republicanos careciam de maturidade política, na verdade, era um movimento ainda buscando uma identidade, se perderam ao ocupar o poder. Tinham exagerado ao atirar pedras no governo e, agora, não sabiam o que fazer com as rédeas do país nas mãos. Por décadas gastaram energia atacando o governo e se esqueceram de modernizar suas próprias ideias. Acreditavam que bastava uma fórmula escrita e daí surgiria uma grande nação. Aliás, o movimento republicano era "expert" em analisar, avaliar e julgar os males do mundo lá fora, porém incapazes de diagnosticar nossas mazelas.

Produziram uma obra belíssima, contudo fadada ao fracasso, vale dizer que na realidade essa Constituição nunca foi imposta, mesmo apresentando alguns traços de modernidade, sua ideologia se revestia do moralismo francês, do liberalismo inglês e do federalismo americano. Acontece que o momento histórico, levou seus seguidores e fanáticos a uma profunda decepção, tendo alguns proclamado: Não era esta a república dos meus sonhos! A falta de uma classe social que encarnasse o espírito da Constituição e pelejasse por ela, produziu fatos que por si só conspiraram contra esses ideais. $\mathrm{O}$ grupo republicano a poucos representava, e, não tinha uma elite que alavancasse e desse suporte a esses ideais. Era um grupo formado por elementos oriundos de várias classes e com aspirações distintas, portanto, sem opinião unificada e pensamento organizado. 
Outro fator conspiratório era o momento econômico, a abolição do trabalho servil abalou as estruturas econômicas da sociedade e deixara órfã a aristocracia, golpeada na sua atividade mais lucrativa: o plantio. Despojada de seu "status quo", a aristocracia começa a enxergar no Estado a tábua de salvação, a burocracia era a solução, o emprego público o "sonho ideal", enfim, continuaria a ser aristocracia, porém, alicerçada nas estruturas da união, estados e municípios. A fragmentação do Império dera lugar a um estado polvilhado de clãs locais, onde cada chefe político desarticulado da unidade nacional impunha seu poder. Esse novo regime democrático dissemina pelo país a cultura do emprego público, o voto comprado, os partidos sem representação junto ao povo e acima de tudo a certeza e que o sufrágio universal traria o tão esperado messias, que de posse de uma constituição enveredaria o país para o palco das grandes nações.

O idealismo republicano falhou principalmente por não ter percebido o momento histórico da época, falhou por não saber interpretar as condições do povo e falhou de forma retumbante ao acreditar que bastaria uma fórmula escrita, e pronto, teriam uma grande nação. Com o passar do tempo e a desilusão com a Constituição Republicana, apela-se à violência, o debate político dá lugar ao assassinato político, apela-se aos quartéis, caminho que não tem solucionado a questão da democracia. Na verdade, tudo nasce na fonte de um só problema: o desacordo entre a constituição e a realidade nacional.

Despreza-se a opinião pública. Até porque não temos uma opinião pública. Ingrediente básico para o sucesso de uma democracia de opinião organizada. Sem ela, a opinião pública, torna-se impossível o surgimento do sufrágio universal de classe e não individualista na qual os eleitos possam com base na opinião pública defender a vontade do povo. Para os republicanos, os partidos políticos são os centros de irradiação da opinião pública, surge desta premissa a ideia de organizar partidos com seus chefes políticos, tendo como alicerce a livre expressão democrática. Os republicanos da constituinte construíram um regime político baseado no pressuposto da opinião pública organizada arregimentada e militante. Ora, como esta opinião pública não existia e ainda não existe, logo: o mecanismo idealizado pelos republicanos estava fadado ao fracasso.

Os republicanos entenderam que o regime de opinião pública não resulta apenas do voto, mas sim pela solidariedade de classe, como entre nós essa solidariedade não existe, com exceção dos militares, logo, o voto torna-se individualista, vazio, em seu lastro patriota. Não existe interesse coletivo, este sentimento presente na raça germânica, em especial os ingleses, essa ausência de interesse coletivo é que gera a falência das instituições. Observa-se em cada 
cidadão o desinteresse pelo júri, pelo serviço militar e pelo serviço eleitoral, este último apresenta o seguinte mecanismo: o eleitor vai à urna apenas comprazer os interesses de um chefe local. Desta forma, não se promove o fortalecimento das instituições.

Assim sendo, a ausência da opinião pública organizada e da opinião pública democrática, resultou na falência da carta de 24 de fevereiro, ficando o povo incapaz de organizar os quatro poderes. Contudo, a solução mais adequada seria não destruir esses poderes, mas sim educa-los.

$\mathrm{Na}$ esfera administrativa esse quadro promove uma série de presidentes que organizam ou são forçados a organizar um programa de governo sem nenhuma continuidade. Agrava-se o quadro quando a nação espera de seu mandatário soluções messiânicas, quando o correto seria a organização de classe, que com seus interesses levassem ao presidente eleito suas demandas. Confia-se demais nos partidos e nos políticos o que não ocorre em outros países, pois neles a solução não é mágica, mas participativa. Não temos como culpar os governos por não serem patriotas, na verdade, é na participação e na organização das ideias que os obrigaremos a serem patrióticos, até porque não existem governos patrióticos, só os são pela força da organização e da pressão das classes. Conclui-se que nem todos os problemas de uma nação serão resolvidos apenas com voto e a reforma política na busca de uma democracia de opinião organizada.

Vendo dessa maneira os republicanos de 24 de fevereiro, partindo de uma utopia, até mesmo romântica falhariam em qualquer empreitada em qualquer outro país, pois cometeriam os mesmos erros, e o pior deles, não fazer corretamente a leitura entre a realidade de seus sonhos e a realidade de nosso povo.

Ao analisar a questão do voto Oliveira Viana, conclui (VIANA, 1939, p. 85-90) que, a ideia de que o voto resolve todos os problemas é uma falácia, qualquer nação que queira evoluir, deve partir do princípio que a opinião pública organizada deve preceder o ato individual de votar. Quem dá consistência ao voto é a organização e não o contrário, até porque existem outras formas de expressão e participação popular, o voto é apenas uma dela.

Ora, se a independência não nasceu do voto, se a abolição e a república não nasceram do voto, movimentos estes que nasceram da pressão da organização e confluência de interesses, por que tudo agora seria solucionado num passe de mágica pelo voto? A democracia pode realizar eleições mesmo sem eleitores. O voto tem que ser uma manifestação espaçada, periódica, mas não a principal. No Brasil atualmente só existem dois instrumentos fomentadores de opinião pública, os jornais e os partidos, embora às vezes a imprensa se torne um braço dos partidos. Quanto aos governos não há de considera-los formadores de opinião, 
pois seus atos são por vezes oriundos de interesses escusos, como a maioria dos instrumentos de opinião pública funciona de forma descontínua, reside aí um grande problema a ser resolvido: fazer com que os instrumentos formadores e fomentadores de opinião pública atuem de maneira contínua, para que aos poucos se eduque as instituições e se construa uma democracia de opinião organizada.

Oliveira Viana em "O idealismo da Constituição" defende-se que o movimento em prol da velha "tese" democracia revive-se antigos debates sobre soberania do povo, direito do sufrágio universal, representação política e princípio de liberdade. Ressalta-se a importância de que esses debates ocorressem em São Paulo, centro de irradiação de ideias. Com um olhar sobre os agitadores. Oliveira Viana, classifica-os de mais interessantes que as ideias, pois constata que a mentalidade dos agitadores de hoje, nada mais é que a mentalidade dos agitadores de ontem: os mesmos que sonharam a independência, a Constituinte Imperial, a Constituinte Republicana, etc. São na verdade ideias, processos e objetivos guardados por décadas em "gavetas" e ocasionalmente usadas. O que difere é que os agitadores de hoje podem refletir com base numa experiência de Democracia.

O ponto crucial da questão (VIANA, 1939, p. 11) é como esses agitadores de hoje usaram essa experiência na formação de suas ideias políticas e reformadoras. A resposta deve passar pela categoria de espírito de cada agitador, pois, tanto faz, citando Jung (VIANA, 1939, p. 11) "cem anos de experiência, um ano de experiência ou nenhum ano de experiência, uma vez que tudo se iguala a nada". No caso dos republicanos, citando Nabuco (VIANA, 1939, p. 11): “uma pura arte de construção no vácuo: as bases são as teses e não os fatos; o material, ideais e não os homens; a situação, o mundo e não a paz; os habitantes, as gerações futuras e não as atuais" O grande problema é evoluir da situação atual (Democracia de Opinião) para uma Democracia de Opinião Organizada.

Quando confrontadas, a Constituição Imperial sobre a Constituição Republicana, veremos que a primeira tinha a seu favor as grandes lideranças do país, tanto com campo da inteligência, do prestígio cultural, do caráter e da condição social, representantes da nação comprometidos com um ideário de construção de um país. Já a Constituição Republicana, nascia sob o aval de "agitadores" que acreditavam que apenas belos artigos promoveria o salto do país para patamares mais evoluídos. Com o advento da República, essas velhas lideranças foram colocadas de lado, abrindo espaço para inúmeros clãs, que não só fragmentou o poder central, como também, a unidade de pensamento já existente. Esses grupos espalhados pelo país deram origem aos partidos políticos, sem estruturas de caráter, escrúpulos e experiência, 
tomando de "assalto" o poder das lideranças da Constituinte Imperial, dotadas de valores e ideais políticos.

Acontece que os "moços" republicanos careciam de maturidade política. Na verdade, era um movimento ainda buscando uma identidade, se perderam ao ocupar o poder. Tinham exagerado ao atirar pedras no governo e, agora, não sabiam o que fazer com as rédeas do país nas mãos. Por décadas gastaram energia atacando o governo e se esqueceram de modernizar suas próprias ideias. Acreditavam que bastava uma fórmula escrita e daí surgiria uma grande nação. Aliás, o movimento republicano era "expert" em analisar, avaliar e julgar os males do mundo lá fora, porém incapazes de diagnosticar nossas mazelas.

Produziram uma obra belíssima, contudo fadada ao fracasso, vale dizer que na realidade essa Constituição nunca foi imposta, mesmo apresentando alguns traços de modernidade. Sua ideologia se revestia do moralismo francês, do liberalismo inglês e do federalismo americano. Acontece que o momento histórico, levou seus seguidores e fanáticos a uma profunda decepção, tendo alguns proclamado: "Não era esta a república dos meus sonhos!" A falta de uma classe social que encarnasse o espírito da Constituição e pelejasse por ela, produziu fatos que por si só conspiraram contra esses ideais. O grupo republicano a poucos representava, e, não tinha uma elite que alavancasse e desse suporte a esses ideais. Era um grupo formado por elementos oriundos de várias classes e com aspirações distintas, portanto, sem opinião unificada e pensamento organizado.

Outro fator conspiratório era o momento econômico, a abolição do trabalho servil abalou as estruturas econômicas da sociedade e deixara órfã a aristocracia, golpeada na sua atividade mais lucrativa: o plantio. Despojada de seu "status quo", a aristocracia começa a enxergar no Estado a tábua de salvação, a burocracia era a solução, o emprego público o "sonho ideal", enfim, continuaria a ser aristocracia, porém, alicerçada nas estruturas da união, Estados e municípios. A fragmentação do Império dera lugar a um Estado polvilhado de clãs locais, onde cada chefe político desarticulado da unidade nacional impunha seu poder. Esse novo regime democrático dissemina pelo país a cultura do emprego público, o voto comprado, os partidos sem representação junto ao povo e acima de tudo a certeza e que o sufrágio universal traria o tão esperado messias, que de posse de uma constituição enveredaria o país para o palco das grandes nações.

O idealismo republicano falhou principalmente por não ter percebido o momento histórico da época, falhou por não saber interpretar as condições do povo e falhou de forma retumbante ao acreditar que bastaria uma fórmula escrita, e pronto, teriam uma grande nação. 
Com o passar do tempo e a desilusão com a Constituição Republicana, apela-se à violência, o debate político dá lugar ao assassinato político, apela-se aos quartéis, caminho que não tem solucionado a questão da democracia. Na verdade, tudo nasce na fonte de um só problema: o desacordo entre a constituição e a realidade nacional.

Despreza-se a opinião pública. Até porque não tínhamos uma opinião pública. Ingrediente básico para o sucesso de uma democracia de opinião organizada. Sem ela, a opinião pública, torna-se impossível o surgimento do sufrágio universal de classe e não individualista na qual os eleitos possam com base na opinião pública defender a vontade do povo. Para os republicanos, os partidos políticos são os centros de irradiação da opinião pública. Surge desta premissa a ideia de organizar partidos com seus chefes políticos, tendo como alicerce a livre expressão democrática. Os republicanos da constituinte construíram um regime político baseado no pressuposto da opinião pública organizada arregimentada e militante. Ora, como esta opinião pública não existia e ainda não existe, logo: o mecanismo idealizado pelos republicanos estava fadado ao fracasso.

Os republicanos entenderam que o regime de opinião pública não resulta apenas do voto, mas sim pela solidariedade de classe, como entre nós essa solidariedade não existe, com exceção dos militares, o voto torna-se individualista, vazio, em seu lastro patriota. Não existe interesse coletivo, este sentimento presente, em especial, na raça germânica, e também nos ingleses. Essa ausência de interesse coletivo é que gera a falência das instituições. Observa-se em cada cidadão o desinteresse pelo júri, pelo serviço militar e pelo serviço eleitoral, este último apresenta o seguinte mecanismo: o eleitor vai à urna apenas comprazer os interesses de um chefe local. Desta forma, não se promove o fortalecimento das instituições.

Assim sendo, a ausência da opinião pública organizada e da opinião pública democrática, resultou na falência da carta de 24 de fevereiro de 1891, ficando o povo incapaz de organizar os quatro poderes. Contudo, a solução mais adequada seria não destruir esses poderes, mas sim educa-los.

$\mathrm{Na}$ esfera administrativa esse quadro promove uma série de presidentes que organizam ou são forçados a organizar um programa de governo sem nenhuma continuidade. Agrava-se o quadro quando a nação espera de seu mandatário soluções messiânicas, quando o correto seria a organização de classe, que com seus interesses levassem ao presidente eleito suas demandas. Confia-se demais nos partidos e nos políticos o que não ocorre em outros países, pois neles a solução não é mágica, mas participativa. Não temos como culpar os governos por não serem patriotas, na verdade, é na participação e na organização das ideias que os obrigaremos a serem 
patrióticos, até porque não existem governos patrióticos, só os são pela força da organização e da pressão das classes. Conclui-se que nem todos os problemas de uma nação serão resolvidos apenas com voto e a reforma política na busca de uma democracia de opinião organizada.

Vendo dessa maneira os republicanos de 24 de fevereiro de 1891, partindo de uma utopia, até mesmo romântica falhariam em qualquer empreitada em qualquer outro país, pois cometeriam os mesmos erros, e o pior deles, não fazer corretamente a leitura entre a realidade de seus sonhos e a realidade de nosso povo.

Ao analisar a questão do voto, Oliveira Viana conclui (VIANA, 1939, p. 85-90) que a ideia de que o voto resolve todos os problemas é uma falácia, qualquer nação que queira evoluir deve partir do princípio que a opinião pública organizada deve preceder o ato individual de votar. Quem dá consistência ao voto é a organização e não o contrário, até porque existem outras formas de expressão e participação popular, o voto é apenas uma dela.

Ora, se a independência não nasceu do voto, se a abolição e a república não nasceram do voto, movimentos estes que nasceram da pressão da organização e confluência de interesses, por que tudo agora seria solucionado num passe de mágica pelo voto? A democracia pode realizar eleições mesmo sem eleitores. $O$ voto tem que ser uma manifestação espaçada, periódica, mas não a principal. No Brasil atualmente só existem dois instrumentos fomentadores de opinião pública, os jornais e os partidos, embora às vezes a imprensa se torne um braço dos partidos. Quanto aos governos não há de considera-los formadores de opinião, pois seus atos são por vezes oriundos de interesses escusos, como a maioria dos instrumentos de opinião pública funciona de forma descontínua, reside aí um grande problema a ser resolvido: fazer com que os instrumentos formadores e fomentadores de opinião pública atuem de maneira contínua, para que aos poucos se eduque as instituições e se construa uma democracia de opinião organizada.

\section{CONSIDERAÇÕES FINAIS}

É imprescindível salientar que a visão de que o Brasil se situa em uma condição periférica (aspecto locacional) em relação a países considerados cêntricos não suporta sustentação filosófica e científica, ou seja, não há plausibilidade tampouco bases racionais para a defesa de tal suposição. Da mesma forma e no mesmo sentido a disciplina "Pensamento Constitucional Brasileiro" ao invés de "Teoria Constitucional Brasileira" se apresenta como 
uma falta de paralelismo que de fato sugere a influência da ideologia periférica do país. Esse tipo de pensamento influenciou em demasia o processo Constitucional nacional sendo alvo de observações e críticas contundentes tanto de Alberto Torres como em Oliveira Viana.

Os principais pontos defendidos por Alberto Torres são: (1) enxergava a necessidade de orientar e organizar o país em função de suas próprias características, peculiaridades e fisionomia, o que evitaria a desordem social e moral e traria desenvolvimento ao Brasil, sendo assim, se apega na ordem e no governo dos mais capazes para direcionar o país para o progresso; (2) Criticava o mimetismo (cópia) das ideias e das normas trazidas do exterior, denunciava deste modo a alienação de ideias que estava presente no Brasil; (3) Defendia a ideia de que o povo brasileiro era nobre, porém regido por uma Constituição que não correspondia aos anseios e interesses nacionais, não somente estava em desacordo com as peculiaridades geográficas, econômicas, sociais, políticas, históricas do País; (4) Apego à hierarquia e uma força maior da União sobre os Estados; (5) Denunciava a exploração das riquezas nacionais pelo capital estrangeiro, era defensor de Estatizações e que se deveria haver subsídios para fomento à economia direcionada a Brasileiros ao invés de colonos estrangeiros; (6) Via no país vocação agrícola; (7) era crítico do comunismo e do socialismo embora enxergasse a necessidade de haver respeito aos direitos sociais da classe trabalhadora; (8) Defendia a mudança do nome "Estados Unidos do Brasil” para "República Federativa do Brasil” a qual estaria mais de acordo com a configuração do país o qual não tinha como Estados membros a base da política nacional; (9) Defendia a liberdade de crença e de opinião, ademais, que o Estado fosse leigo; (10) Elenca diversos pontos em que pudesse haver intervenção Federal nas províncias, ou seja, era intervencionista em razão dos anseios nacionais que deveriam sobrepujar os interesses provinciais e partidários, no entanto intervenções que primeiramente deveriam sempre ser amistosas; (11) Advoga por meios que pudessem fazer a Constituição mais efetiva, como o remédio Habeas Corpus e o recurso extraordinário; (12) Defende a restrição da vontade popular na gestão da política pública, esta que deveria ser feita "pelo povo e para o povo" por intermédio dos mais capazes; (13) critica o comércio como agente de iniciativa da economia; (14) frisa a necessidade de haver intervenção governamental na economia para que houvesse harmonia entre esta e os anseios nacionais, conjuntamente com o desenvolvimento da nação; (15) A tributação de capitais e rendas improdutivas; (16) A criação do poder coordenador; (16) A interpretação da Constituição com base na finalidade e na razão das normas; (17) A mudança na composição da câmara que passaria a ser composta por 125 deputados, eleitos pelo sufrágio direto, sendo a metade por distritos eleitorais, $25 \%$ por Estados, e $25 \%$ por todo país; (18) O 
senado seria composto por representantes de todos os Estados e pelo mais diversos seguimentos da sociedade civil organizada e até pelo clero; (19) O mandato de presidente passaria a ter oito anos.

As mazelas do nosso nacionalismo apresentadas por Oliveira Viana na obra "O Idealismo da Constituição" são extremamente atuais, não somente talvez até possamos classificá-la de atemporal, entre essas mazelas, podemos elencar as mais contundentes na difícil tarefa de se construir uma nação, são elas (1) a falta de aprendizagem com as experiências históricas, (2) a ausência de classes sociais que apresentem unidade de pensamento em relação as suas demandas, (3) o ideário de que o voto é uma solução mágica e salvadora, (4) partidos políticos fracos e sem representação popular, (5) a esperança de que das eleições surja um "Messias" que solucione os problemas nacionais, (6) a incapacidade de se fazer uma leitura por parte dos dirigentes políticos da realidade de nosso povo, (7) o descompasso entre as leis e a realidade, (8) a visão de que o Estado deva ser o provedor de boa parte da população, (9) a presença do moderno coronelismo embutido nos partidos e perpetuado por inúmeras "clãs", (8) a falta de uma Opinião Pública organizada e por fim, (9) a incapacidade criarmos mecanismos contínuos de organização em busca da formação dessa Opinião Pública. Contudo, o próprio autor sinaliza uma saída ao afirmar que apesar das adversidades, a busca por uma Democracia de Opinião Organizada não passa pela destruição das instituições, mas sim pelo seu aperfeiçoamento.

Todos estes pontos defendidos por Alberto Torres E Oliveira Viana tiveram influências enormes na formação política, jurídica e ideológica da nação brasileira.

\section{REFERÊNCIAS}

CIVITA, Victor. Nova História da Música Popular Brasileira: Silas de Oliveira/Mano Décio da Viola. 2. ed. São Paulo: Abril Cultural, 1977.

LYNCH, Christian Edward Cyril. Por que pensamento e não teoria? A imaginação políticosocial brasileira e o fantasma da condição periférica (1880-1970). Rio de Janeiro: Revista Dados, v. 56, n. 4, oct./dec. 2013.

LYNCH, Christian Edward Cyril. Cultura política brasileira. In: Gustavo Santos e Éder Brito, Política no Brasil. São Paulo: Oficina Municipal. 2015. 
TORRES, Alberto. A organização nacional. 2. ed. São Paulo, Fonte digital. 2002.

VIANA, Oliveira O idealismo da Constituição. Rio de Janeiro, Terra do Sol. 1939.

\title{
ALBERTO TORRES AND OLIVEIRA VIANA'S NATIONALISM IN THE CONSTRUCTION OF THE BRAZILIAN CONSTITUTIONAL THOUGHT
}

\begin{abstract}
The aim is to study and question, in this study, the concept of "periphery" as a Brazilian characteristic in relation to alleged centered countries, not only a hypothetical hierarchically inferior position in cultural areas, social policies etc. It analyzes the theories that defend and attack such ideas Always, seeking an agreement that does not fall into academic anachronism either delete the current period sine qua non characteristics and peculiarities for the criticism of the value judgments of the time. Moreover, the work used is "The National organization" by Alberto Torres and "The idealism of the Constitution" by de Oliveira Viana as essential bibliography to the understanding of the influence of nationalist thought in the Brazilian constitutional movement, in addition, the practical influence of its theories in history.
\end{abstract}

Keywords: Foreign nationalism. Inadequacy. Nationalism. 